\title{
El lector / The reader: entre el amor a la literatura y la banalidad del mal
}

\section{The reader / El lector: between love for Literature and banality of evil}

\author{
María Cecilia Reviglio \\ Universidad Nacional de Rosario - Conicet \\ ceciliareviglio@arnet.com.ar
}

\section{Resumen:}

Todas las críticas al filme El lector apuntan al modo en que la historia se mete en el drama del holocausto nazi desde la vida de postguerra de una guardiana de Auswchitz y de cómo aún después de ese período, sigue afectando a inocentes involucrados afectivamente con su presente.

De todos modos, lo singular en este relato es el lugar que ocupa la lectura para los seres humanos. Este escrito intentará reflexionar sobre el lugar de la lectura como actividad cognitiva y subjetiva, de la lectura en voz alta y silenciosa, de la escritura y de las historias en la vida de las personas.

Palabras clave: El Lector, holocausto, memoria, lectura, literatura

\begin{abstract}
:
All criticism of the film The Reader points to how the story gets in the Nazi Holocaust drama from the life of a guardian of postwar Auswchitz and how even after that period, continues to affect innocent emotionally involved with her present.

However, the unique element is the place to read for humans. This paper will attempt to think of the place of reading as a cognitive and subjective activity, the reading aloud and silently, the writing and the stories in people's lives.
\end{abstract}

Key words: The Reader, Holocaust, memory, reading, literature 


\section{Introducción}

Todas las críticas al filme El lector (The reader, dir. Stephen Daldry, 2008) apuntan al modo en que la historia se mete en el drama del holocausto nazi desde un hilo de agua conformado por la vida de postguerra de una guardiana de Auswchitz y de cómo aún después de ese período algo de su "¿maldad?" sigue afectando a inocentes que, ajenos a su crimen pasado, están involucrados afectivamente con su presente. De hecho, en una de las escenas finales de la película — adaptación genial de la novela homónima de Bernard Schlink ${ }^{1}$ - , una sobreviviente del campo le señala al protagonista ya adulto la magnitud del daño que Hanna le propinó en una relación amorosa fundante para la subjetividad del protagonista, entonces adolescente. "En los últimos años cuando estaban en contacto, ¿tenía la sensación de que ella sabía lo que le había hecho?”, pregunta la sobreviviente en una de las últimas páginas del libro.

Sin embargo, este trabajo no indagará solamente esta manera particular de abordar el Holocausto, sino que también intentará analizar el modo en que, entramado en el drama judío alemán, aparece otro tema al que la crítica no ha prestado demasiada atención, tal vez porque el peso del Holocausto lo ha eclipsado. Lo que a mi juicio es singular es el lugar de la lectura y a través de ella, la posibilidad de acceder a la literatura para los seres humanos. A partir de esa intuición — que allí radica la singularidad de esta historia que la diferencia de las nuevas historias sobre el holocausto - este escrito intentará reflexionar sobre el lugar de la lectura como actividad cognitiva y subjetiva, de la lectura en voz alta y de la silenciosa, de la escritura y de las historias en la vida de las personas.

En primer lugar, el escrito repasará las críticas y repercusiones del filme en la prensa argentina y en algunos otros países como modo de hacer pie en los discursos mediáticos sobre la historia para, a partir de allí, continuar analizando aquellos aspectos no enfatizados en los medios. En segundo lugar, se hará referencia a una serie de elementos conceptuales referidos al mundo de la lectura, para finalmente, dar paso al análisis de la valoración social de la alfabetización.

\footnotetext{
${ }^{1}$ En la contratapa del libro se lee: "Michael Berg tiene quince años. Un día, regresando a casa del colegio, empieza a encontrarse mal y una mujer acude en su ayuda. La mujer se Ilama Hanna y tiene treinta y seis años. Unas semanas después, el muchacho, agradecido, le lleva a su casa un ramo de flores. Éste será el principio de una relación erótica en la que, antes de amarse, ella siempre le pide a Michael que le lea en voz alta fragmentos de Schiller, Goethe, Tolstói, Dickens... El ritual se repite durante varios meses, hasta que un día Hanna desaparece sin dejar rastro.

"Siete años después, Michael, estudiante de Derecho, acude al juicio contra cinco mujeres acusadas de criminales de guerra nazis y de ser responsables de la muerte de varias personas en el campo de concentración del que eran guardianas. Una de las acusadas es Hanna. Y Michael se debate entre los gratos recuerdos y la sed de justicia, trata de comprender qué llevó a Hanna a cometer esas atrocidades, trata de descubrir quién es en realidad la mujer que amó". Hasta aquí, la reseña del libro, que oculta — dado que es una sinopsis para el futuro lector de la novela- que durante el juicio Michael descubre que Hanna es analfabeta y que su afán de ocultarlo ha determinado muchas de las decisiones de su vida, aún la de alistarse en las SS. Hanna es condenada a cadena perpetua —una vez más, como resultado de sus esfuerzos por ocultar su analfabetismo- y luego de algunos años Michael comienza a enviarle a la prisión cassettes donde él mismo le lee las historias que le había leído en su adolescencia y muchas otras más. Finalmente Hanna aprende a leer y escribir y, luego de obtener la libertad condicional después de dieciocho años, se suicida la noche anterior a su salida.
} 


\section{El Lector en la crítica cinematográfica periodística y en algunos sitios web}

El Lector, que le valió el Oscar a Kate Winslet, plantea dilemas sobre el amor, la inocencia, la lealtad y la culpa”. Estas palabras, encabezadas por el cinematográfico título Los imperdonables son las que Clarín eligió para introducir una crítica al filme que no pasa de lo técnico. Elogios a las actuaciones, la dirección, la banda de sonido y la iluminación dicen poco de la historia que, adelantan, se divide en dos a partir de una escena, dejando de un lado del celuloide una "historia bien rosa” y del otro, una historia "oscura”, sombría (Clarín de 7/5/09). La narración breve de la historia al inicio de la crónica no pasa de un relato ascético de los hechos primeros y del planteo implícito, para no develar el secreto del filme, al que llaman una "controversia".

Página 12, en cambio, se anima a una crítica más profunda en tanto intenta reflexionar sobre los dilemas que el film le presenta tanto a sus protagonistas como a sus espectadores. Comienza por explicitar ciertas preguntas que la historia pareciera dejar abiertas acerca de la sensibilidad artística de quien cotidianamente envía "gente a la muerte", y la posibilidad de redención de los crímenes a través del arte. Su título "Preguntas sin respuestas" y la referencia ya desde su bajada a la obra literaria que dio origen al filme, ponen el acento en el efecto que la versión cinematográfica deja en sus espectadores a partir del planteo de interrogantes que la película se niega a responder. Asimismo, también pone de relieve el aspecto controversial de la novela que publicada en Alemania, dividió "a la nación entera entre el elogio y la acusación” (Página 12 de 7/5/2009).

La crítica de La Nación, por su parte, es la menos favorable de todas, tanto con el relato cinematográfico como con el literario. En su nota "El lector, el amor en los tiempos de la culpa" cuestiona lo que llama "ese velado ánimo complaciente" del relato y una "más que equívoca noción de autosacrificio", aunque reconoce que la historia "aborda cuestiones conflictivas en torno del impacto que la culpa produjo en la generación alemana posterior al holocausto”. Distingue en el film tres partes: la relación entre Hanna y Michael, signada por el erotismo y la literatura; "la de la turbadora revelación y el provocativo dilema" cuando Michael descubre casi al mismo tiempo, que Hanna fue guardiana de un campo de concentración durante la Segunda Guerra Mundial y que su avidez por la literatura estaba marcada por su analfabetismo; y por último, "la de la expiación".

Sin embargo, y en confrontación con la interpretación de esta última parte del filme, su propio director, en diálogo con el diario francés Le Figaro, expresa:

Es imposible perdonar a Hanna. Cada una de las elecciones de su vida estaban relacionadas con su pesado secreto: el analfabetismo. Guardiana de campo en Auschwitz, ella no dará ninguna salida durante una marcha a las deportadas encerradas dentro de una iglesia en llamas. No abrirá las puertas y dejará que esas mujeres se quemen vivas. La máquina infernal del genocidio implica que personas ordinarias cometan crímenes imperdonables. Es la banalidad del mal ${ }^{2}$ (Le Figaro del $15 / 7 / 2009)$.

\footnotetext{
${ }^{2}$ Esta última expresión hace referencia a una idea que elaborara Hannah Arendt luego de presenciar el juicio a un burócrata nazi, Adolph Eichmann en Israel y que le valiera muchas críticas en su momento. Al respecto, en un número de la Revista Debats dedicado al pensamiento de Arendt, Ingeborg Nordmann afirma: "Su contacto personal
} 
Una crítica del New York Times, en tanto, cuestiona la necesidad de "otro film sobre el Holocausto" y la supuesta intención de la película de hacer que el espectador se sienta cómodo con el relato de un hecho histórico y experimente alguna piedad hacia Hanna. Asimismo, en el plano técnico critica la utilización de la luz que embellece incluso la escena de la visita de Michael al campo de exterminio (The York Times de 10/12/2008). Cabe destacar que son muchos los comentarios de los lectores que no acuerdan con la valoración negativa de la crítica.

Un repaso rápido por las páginas web que resultan de la búsqueda de El lector no aporta análisis muy diferentes. Más o menos calurosas, las críticas en general son buenas. Se destaca un comentario del sitio Cervantes (www.cervantesvirtual.com) que señala a la novela como una excepción dentro del género de novela política, ya que su narrador arriesga "su buena conciencia" y se atreve a tomar un "punto de vista prima facie inmoral: el del antihéroe". Llamativamente, ésta es la única de las críticas encontradas que hacen referencia al título elegido para la novela:

Schlink escoge deliberadamente un punto de vista que nos implica: el del lector (en una novela llamada 'El lector', todos venimos a ser protagonistas). Y desde allí nos conduce inexorablemente a comprender al verdugo. Mostrándonos en él, al débil, al analfabeto, aquel para el cual el mundo es un enigma violento al que sólo puede responder con la violencia de un animal ciego (paréntesis del original).

Algo tienen en común esta reseña y la publicada en el matutino Página 12 y es el acento puesto en las preguntas que deja planteadas la historia. Mientras que el diario argentino afirma:

No se sale de The reader con la higiénica, tranquilizadora sensación de haberse dado un baño de alta cultura o de seriedad intelectual sino con la cabeza llena de preguntas. Preguntas que seguramente exceden la capacidad de respuesta de cada espectador. Es justamente en ese exceso, en esa imposibilidad de respuesta donde reside la gigantesca capacidad de interpelación de la novela de Schlink, que esta versión cinematográfica transmite sin obstruir. $(7 / 5 / 2009)$

el sitio web, por su parte, concluye su reseña con una frase simple pero equivalente: "Llegamos a este libro munidos de nuestras certezas. Y lo dejamos, civilizados por la duda”.

Otra de las reseñas de la novela — publicada en el sitio Leyendo a la sombra (http://leyendoalasombra.blogia.com) - hace referencia al interés relativamente reciente en España acerca de los problemas de la sociedad alemana de posguerra, del cual afirma que "ha

con Eichmann confirmó su tesis anterior: que el nacionalsocialismo no debe ser considerado como el afloramiento de elementos soterrados ajenos a nuestra civilización, sino que es un fenómeno surgido en el seno de esta civilización. Las declaraciones realizadas por Eichmann en el proceso y en torno a él sirvieron para confirmar la tesis de Hannah Arendt con una brutalidad que ni ella misma hubiera sido capaz de imaginar: 'Me quedé totalmente estupefacta ante la evidente vulgaridad del personaje; ante ella resultaba imposible buscar algún tipo de raíces o de motivaciones profundas que explicaran su innegable perversión. Sus acciones eran monstruosas, pero su autor —al menos aquella persona, tan activa tiempo atrás, que se hallaba ante el tribunal- era completamente normal y corriente, sin nada de demoníaco o de monstruoso'. Lo que de nuevo tienen estas afirmaciones es su observación sobre la 'breve distancia' que separa al ciudadano medio Eichmann del genocida Eichmann" (Nordmann; 1991: 43) 
contribuido a la revisión que se está haciendo de ciertos aspectos de nuestra guerra civil (se refiere, por supuesto a la Guerra Civil española), la posguerra y el franquismo” (paréntesis de la autora). En la misma línea, el artículo ya citado del sitio cervantesvirtual, hace referencia a la realidad latinoamericana: "Leído en las sociedades latinoamericanas de fin de milenio y posguerra sucia, este libro deja lecciones insoslayables”.

\section{En busca de una tradición fílmica literaria para El Lector}

¿Qué preguntarse frente a El Lector, en su versión fílmica o bien literaria? El primer impulso indica pensar con qué otros relatos o discursos hace serie. Parece difícil dar una respuesta unívoca, aunque una de las primeras que saltan a la luz es aquella que indica que es un relato que no se centra en la mirada de las víctimas del holocausto. No cuenta la historia de prisioneros de los campos, ni de personas cuyas familias judías en Alemania corren riesgos, ni de soldados de los aliados. No muestra la guerra ni habla demasiado de ella. De hecho la historia comienza en 1958, trece años después de finalizada y cuenta sucesos que, si bien relacionados, ocurrieron luego del conflicto. ¿Podría decirse que los crímenes nazis son sólo el contexto de una historia de amor tortuosa o hay allí un intento de elaboración literaria del drama? A juzgar por las críticas ya analizadas, el nazismo no es sólo un contexto para un relato "bien rosa", como lo llamó el cronista de Clarín - al menos en su primera parte - sino que es un intento de mostrar los efectos que la historia puede tener aun en personas que no la han vivido. La historia intenta dar cuenta de la manera en que las consecuencias de la experiencia de los campos de exterminio - esta vez para una guardiana, no para un prisionero - signan la vida de los alemanes, aun los nacidos poco antes de finalizada la guerra, como el protagonista Michael Berg quien en 1958 tiene 15 años.

La pregunta insiste. ¿Con qué otros relatos hace serie? Es posible encontrar una clave para esta respuesta en una entrevista al escritor de la novela, el juez Bernhard Schlink, publicada en Página 12 en el año 2005, cuando el escritor visitó la Argentina:

La memoria acerca del nacionalsocialismo lleva más de cincuenta años y esto hace que se vaya transformando y adoptando formas diferentes. En algún momento, lo más importante era juzgar de manera clara, pero en la medida que uno se va distanciando temporalmente es más fácil ver los matices. Mi libro se publicó justamente en un momento de quiebre entre un período en el que sólo se buscaba juzgar y otro en el que se necesitaba distancia para mirar. Y creo que mi novela ha aportado algo a este cambio, generó un sentimiento hacia esa complejidad: quienes participaron del nazismo y cometieron monstruosidades no son necesariamente monstruos. ${ }^{3}$ (Página 12 del $4 / 5 / 2005)$

\footnotetext{
${ }^{3}$ Esta apreciación también recuerda a las reflexiones del fiscal argentino Luis Moreno Ocampo, quien participara al juicio a las Juntas Militares en 1985, y en su libro "Cuando en poder perdió el juicio", cuenta lo siguiente: "Durante el juicio, una periodista norteamericana me preguntó una vez si yo creía que los militares argentinos era un grupo de gente particularmente sádica. (...) Sé, sin embargo, la tranquilizadora respuesta que ella, como muchas, esperaba oír: que los militares argentinos eran irracionales en su cruzada de horror y violencia sádica. (...) Los crímenes del Proceso fueron crímenes racionales. Fueron el resultado de un conflicto entre diferentes reglas: las de la ley, las del
} 
Es decir, la novela se inserta en la serie de los relatos que no buscan llanamente juzgar, sino más bien, comprender; que no buscan concientizar, sino generar preguntas. En este sentido, es interesante el fragmento del libro donde el protagonista — narrador de la historia — da cuenta de la imposibilidad de realizar al mismo tiempo ambas acciones: condenar y comprender:

Quería comprender y al mismo tiempo condenar el crimen de Hanna. Pero su crimen era demasiado terrible. Cuando intentaba comprenderlo tenía la sensación de no estar condenándolo como se merecía. Cuando lo condenaba como se merecía, no quedaba espacio para la comprensión. (Schlink; 2000: 148)

Se podría pensar que el relato - ya no importa si literario o cinematográfico - hace serie, por ejemplo, con la película La caída que narra los últimos días de Adolfo Hitler y a la que también se le criticó la presentación "humanizada” del líder del nazismo alemán, así como también la de todo su entorno.

Por esas mismas razones, tanto el libro como la película generaron controversia. Al respecto, en la entrevista publicada en Le Figaro citada anteriormente, Daldry afirma:

Bernhard Schlink habla de los verdugos y no de las víctimas ${ }^{4}$, hay inevitablemente controversia. Y después, se experimenta hacia Hanna, criminal de guerra nazi, sentimientos difusos y ambiguos. Después del proceso y de su condena a cadena perpetua Michael esperaba, como ella había aprendido a leer, que tomara conciencia de sus actos, que tuviera remordimientos. Pero, aún presa, es incapaz de hacerlo. Y es ésa su tragedia. En el film, ella dice: 'Poco importa lo que sienta, poco importa lo que piense, eso no devolverá a los muertos”. (15/7/2009)

En una charla que el mismo autor dio en la Universidad de Humboldt en Berlín en febrero de 2009 respondió a estas cuestiones:

Desde que el libro apareció, estuve afrontando el cargo de que, en el personaje de Hanna Schmitz, el verdugo se convertía en una heroína y adquiría un inaceptable rostro humano. Pero si los todos verdugos son monstruos, el mundo sería simple. (The New Yorker de febrero de 2009)

Una problemática que podría plantearse aquí es la referida a lo que Huyssen llamó "el antagonismo Europa versus Hollywood, arte adecuado contra 'holokitsch' norteamericano (...) lo que está en cuestión es el valor de la obra artesanal del terruño contra el producto

éxito y las de la lealtad al grupo. (...) las reglas de la ley, que se basan en el respeto del otro, habían entrado en conflicto con las reglas del éxito, que los comandantes definieron como 'eliminar físicamente a todo subversivo'" (Moreno Ocampo; 1996: 16-17).

${ }^{4}$ En un fragmento de la novela, también aparece el testimonio de otro colaborador de la dictadura nazi. Cuando el joven, ya estudiante de Derecho, decide conocer un campo de exterminio, tiene un diálogo con una persona que lo conduce hasta el lugar en el que el hombre, fastidiado por el deseo de Michael de conocer el campo, intenta una explicación donde termina develando que él mismo estuvo implicado en una matanza de judíos en Rusia (Cfr. Schlink; op. cit: 141-144). 
norteamericano, masivo y ajeno" (2001: 124), como si, cuestiona el autor, sólo fuera posible recordar "correctamente con la ayuda de la teoría europea y de las estrategias artísticas de la alta modernidad y la vanguardia" (Ibídem: 125). ¿Cómo plantear en este marco la película El Lector? Si bien es un producto de la industria de Hollywood, la historia es una adaptación lograda de una novela alemana, premiada tanto en Alemania como en Italia y Francia 5 .

La cuestión de la supuesta industrialización cultural del holocausto en manos de la industria cinematográfica tampoco pasa inadvertida para el narrador de la novela. En un pasaje, reflexiona acerca de las imágenes del exterminio, que documentaran la vida y el asesinato en los campos y hace una suerte de comparación entre aquellas disponibles en el momento del juicio y las existentes al momento en que se dispone a narrar la historia, a mediados de la década del '90. Mientras que de las primera dice, eran "escasas" (Schlink; 2000: 139), apenas la puerta principal de Auschwitz, con su leyenda "El trabajo los hará libres”, algunas otras imágenes de otros campos como Bergen-Belsen o Birkeneau y algunos relatos de prisioneros que se apagaron rápidamente ${ }^{6}$ hasta los años 80 — cuando hubo un nuevo interés por el tema de la construcción de la memoria $^{7}$

Hoy en día hay tantos libros y películas sobre el tema que el mundo de los campos de exterminio forma ya parte del imaginario colectivo que complementa el mundo real. Nuestra fantasía está acostumbrada a internarse en él, y desde la serie de televisión Holocausto ${ }^{8}$ y películas como La decisión de Sophie y La lista de Schindler, no sólo se mueve en su interior, no se limita a percibir, sino que ha empezado a añadir y decorar por su cuenta" (Ibíd.: 139).

El narrador de El Lector — la novela — es entonces consciente de esta suerte de construcción simbólica del Holocausto y no parece azaroso que los tres títulos que mencione sean producciones americanas sobre el tema. Incluso, en la adaptación de la novela al cine, hay rasgos que pueden leerse en clave de industria cultural o de formato americano. Es probable que algunas pequeñas modificaciones a la historia — detalles que no alteran el nudo central ni el desencadenamiento del relato pero que no pasan desapercibidos - no sólo sean recursos necesarios para la traducción del lenguaje literario al lenguaje cinematográfico, sino que estas alteraciones hayan tomado un giro con ciertas reminiscencias hollywoodenses. Tanto la escena primera que muestra al protagonista adulto luego de una relación aparentemente ocasional, como las pocas escenas en las que el protagonista se encuentra con su hija y que evidencian una relación

\footnotetext{
${ }^{5}$ La novela ha recibido los premios alemanes Hans Fallada de la ciudad de Neumuenster y Ehrengabe de la Dusseldorf Heinrich Heine Society, el premio italiano Grinzane Cavour y el francés Laure Batallion.

${ }^{6}$ Esta apreciación del personaje de la novela está en consonancia con lo que analiza Andreas Huyssen en su artículo "La política y de la identificación: Holocausto y el drama en Alemania Occidental" cuando afirma: "El teatro, los medios y las instituciones educativas podrían haber colaborado en la creación de un clima favorable a la Vergangenheitsbewältigung (que refiere a la superación del pasado) colectiva si en Alemania se le hubiera dado prioridad política y social al confrontamiento con el pasado. Sin embargo, lo que sucedió fue exactamente lo contrario" (Huyssen; 2006: 175).

7 Al respecto, se puede consultar una cantidad enorme de bibliografía tanto teórica como testimonial. Algunos ejemplos son los trabajos de Huyssen (2001 y 2006); Sarlo (2005); las reediciones de los testimonios de Primo Levy (1998) sobre la vida en los campos, Agamben (2000), entre otros.

${ }^{8}$ Sobre la recepción de la serie Holocausto en Alemania Occidental, ver Huyssen (2006; op. cit.).
} 
obturada por cierto hermetismo en el que parece vivir, así como la escena final del filme, en el que Michael se decide a contarle a su hija su historia con Hanna son muestras de esos "detalles" que la película agrega a la historia y que, muy caros a Hollywood, responden a cierto "cliché" del hombre abatido por su pasado que, no obstante, logra vencer ese abatimiento y redimirse en la decisión de poner en discurso su historia, abriéndose a su afecto más cercano.

Asimismo, la decisión del Michael fílmico de enterrar a Hanna en uno de los pueblos donde habían pasado unos días durante un viaje en bicicleta y la visita al lugar con su hija - escenario donde finalmente decide contarle su "secreto" - no aparecen en el personaje literario. Estos "agregados" no son más que "giros" a los que el cine americano ha acostumbrado a sus espectadores. De la misma manera, el reemplazo de una escena más compleja durante el viaje escena en la que incluso se manifiesta un episodio de violencia física de Hanna hacia Michael en medio de un arranque de rabia (pp. 52-58) — por cierto titubeo de Hanna frente al menú de un restaurant durante el mismo evento - imagen estereotipada del analfabetismo secreto a la que han recurrido muchos otros filmes - hacen que la supuesta sorpresa durante el juicio esté un poco anticipada. Es más sorprendente para el espectador — no así para el lector - que Hanna esté acusada en un juicio por crímenes nazis que el hecho de que el fundamento de la relación entre el chico - "kid”, en inglés ... vocablo bastante difícil de reemplazar en español, al menos en Argentina - y la mujer estuviera dado por el analfabetismo de ella, razón por la cual deseaba, necesitaba que Michael le leyera.

\section{La figura del lector en las ficciones analizadas}

En ambos relatos — novela y película — se hace mención a una figura que, encarnada en diferentes personas en los diversos momentos de la trama, tiene una profundidad que debe ser analizada. Esta es la figura del Lector, pero no ya del personaje moderno que la imprenta hizo posible, ese lector solitario y ensimismado producto del encanto que las palabras impresas produjeron en él, sino de una figura mucho más antigua: el lector que lee para otro.

Desde tiempos inmemoriales las personas inventan y desean escuchar relatos. Como afirma el francés Daniel Pennac: “... una novela debía leerse como una novela: ante todo, para aplacar nuestra sed de relatos" (2004: 121). Tanto en la novela como en la película, es Michael el primero que aparece desarrollando esa tarea para Hanna. Todo parece comenzar por puro azar: puesto que él la visita siempre que regresa de la escuela, lleva sus libros con él. Un día, ella repara en ellos, pregunta qué estudia, qué lee y le pide, casi como un juego, que lea para ella. Michael accede rápidamente y así inician una relación sellada por el erotismo y la literatura. Al principio, la lectura viene luego de la relación sexual, hasta que Hanna — que es quien lleva el ritmo del vínculo entre ellos - decide que cambiarán el orden de las actividades: primero la lectura, luego el baño juntos ${ }^{9}$

\footnotetext{
${ }^{9}$ Más allá de las referencias que aparecen acerca de la limpieza de Hanna, el ritual del baño es un elemento presente desde el primer encuentro sexual, cuando al ayudarla con unos baldes de carbón, Michael se ensucia y ella lo hace bañarse para regresar a su casa. Luego del baño tendrán su primera relación sexual.
} 
y por último, el encuentro sexual. Sin embargo, la lectura pareciera ser el elemento decisivo en el vínculo profundo entre ellos. El acto casi altruista de leer para otros los acerca. A eso precisamente hace recordar las palabras de un adulto sobre un docente que solía leer en voz alta a sus estudiantes adolescentes:

¡Lo más importante era el hecho de que nos leyese todo en voz alta! Esta confianza que ponía de entrada en nuestro deseo de comprender... El hombre que lee en voz alta nos eleva a la altura del libro. ¡Verdaderamente da de leer! (cit. en Pennac; op. cit.: 99).

Entre los primeros lectores en voz alta de la historia — al menos, la historia occidentalencontramos a los monjes del monasterio de Monte Casino, Italia, quienes a partir del año 529, leían en voz alta alternadamente unos y otros para el resto del monasterio, como orden de su fundador san Benito, quien impuso esta práctica, ya que "en aquellos tiempos se consideraba que escuchar a un lector era un ejercicio espiritual” (Manguel; 2005: 134). Luego, esta práctica siguió extendiéndose. Entre los siglos XI y XIII encontramos juglares y trovadores, una suerte de narradores que cantaban de memoria versos e historias en ferias y mercados, e incluso en las cortes. También en el seno de las familias, en las cortes e incluso en casas humildes se practicaban las llamadas "lecturas públicas" a cargo de damas de honor, padres o curas como forma de instrucción o entretenimiento (Cfr. Ibídem: 129/130).

En la modernidad, esta práctica se volvió exigua. La invención de la imprenta que posibilitó la proliferación de los libros, hizo que cada vez fuera más sencillo contar con ejemplares, al punto que, alrededor de 1850 se comenzaron a vender en los puestos de diarios de las estaciones de trenes las llamadas "ediciones de bolsillo". La explosión editorial trajo consigo la figura del lector silencioso ${ }^{10}$. No obstante, la práctica de la lectura en voz alta continuó realizándose para los niños aún no adentrados en el mundo de las letras y, según algunos testimonios, en las fábricas para los obreros analfabetos. Al respecto, Alberto Manguel narra una historia sucedida en las empresas de tabaco de Cuba en el año 1860 cuando la aparición de un periódico para la clase obrera hizo caer en la cuenta de que sólo el 15\% de los trabajadores cubanos sabía leer. Dentro de las fábricas se eligieron lectores oficiales que leían en voz alta para sus compañeros las notas publicadas en el periódico La Aurora, pero rápidamente ampliaron el repertorio a textos literarios e históricos. Más tarde, esta práctica fue prohibida por un decreto, ya que, aducían, distraía a los trabajadores de su tarea. Sin embargo, se siguieron realizando lecturas clandestinas e, incluso, en 1869 aparecieron en Estados Unidos, producto de una fuerte inmigración cubana que llevó consigo la institución del lector (Cfr. Ibíd.: 124-127).

\footnotetext{
${ }^{10}$ En La historia de la lectura dirigida por Roger Chartier y Guglielmo Cavallo, Armando Petrucci describe las reglas dictadas por el orden de lectura imperante desde la escuela burguesa del siglo XIX: "se debe leer sentado manteniendo la espalda recta, con los brazos apoyados en la mesa, con el libro delante, etc.; además, hay que leer con la máxima concentración, sin realizar movimiento ni ruido alguno, sin molestar a los demás y sin ocupar un espacio excesivo; asimismo, se debe leer de un modo ordenado respetando la estructura de las diferentes partes del texto y pasando las páginas cuidadosamente, sin doblar el libro, deteriorarlo ni maltratarlo" (el subrayado es mío) (Petrucci; 1998: 543)
} 
Encontramos así, en plena modernidad, la figura del lector en voz alta que habíamos creído desterrada con la imprenta, o, al menos reservada a los niños. Sin embargo, este lector tiene una función cuasi emancipadora: llevar los textos a quienes no poseen las claves para acceder a ellos. Llevar conciencia social e incluso belleza a quienes su analfabetismo, fruto de la desigualdad social había privado de su goce. Eso mismo, aún sin saberlo, es lo que hace Michael con Hanna en la primera parte de la novela y la película: Emilia Galloti, Intriga y amor, Vida de un vagabundo aventurero, Odisea, Guerra y Paz, son los títulos que se mencionan en la novela ${ }^{11}$. Las escenas de lectura que se muestran en el filme están siempre rodeadas de cotidianidad, enmarcadas en la simple vida de dos personas que pasan tiempo juntas mientras desarrollan otras tareas. "Tener a alguien que les leyera, como descubrieron los cigarreros, les permitía compaginar la actividad mecánica y monótona de enrollar las aromáticas hojas de tabaco con aventuras que podían seguir, ideas que considerar, reflexiones que hacer suyas" (Ibíd.: 127). Escenas semejantes pueden observarse en la película. Michael lee mientras Hanna plancha, por ejemplo, o cocina.

Otras escenas, en cambio, la muestran compenetrada con el relato que escucha e, incluso, conmovida. Varios pasajes del libro también dan testimonio de ello: "Hanna escuchaba con mucha atención. Su risa, sus bufidos despreciativos y sus exclamaciones indignadas o entusiastas no dejaban duda de que seguía la trama con interés ...” (Schlink; op. cit.: 45). Y más adelante:

... ahora era ella quien entraba en el mundo de los personajes, con el asombro con que emprendería un largo viaje o penetraría en un palacio en el que se le permitía entrar y quedarse, con cuyas estancias llegaba a familiarizarse, sin por ello perder nunca del todo el recelo. (Ibíd.: 68).

Luego del alejamiento inexplicable de Hanna, Michael deja de llevar a cabo la práctica de la lectura en voz alta y la retoma, ya en la adultez, una vez más para Hanna pero en una relación completamente diferente. La rutina no incluye los rituales del amor ni él puede observar las reacciones de Hanna frente a las historias. Luego de su divorcio de una compañera de facultad, con quien se había casado y tenido una hija, Michael graba los relatos que le envía, sin saber por qué, a la cárcel donde Hanna cumple su condena.

En mis confusas divagaciones de duermevela, llenas de recuerdos y sueños y de atormentadores círculos viciosos, que giraban en torno a mi matrimonio, mi hija y mi vida, se imponía una y otra vez la figura de Hanna. Así que decidí leer para Hanna. Y empecé a grabarle cintas. (Ibíd.: 172)

En esta etapa de la relación entre ellos — relación reducida solamente a las lecturas que Michael graba y envía sin demasiada certeza acerca de qué es lo que sucede del otro lado- el narrador reflexiona acerca de la actividad de la lectura en voz alta:

\footnotetext{
11 En la película cobra alguna significativa importancia "La dama con el perrito" de Chejov, primera lectura que Michael se decidirá a enviarle grabada a Hanna mientras ella está en la cárcel y a partir de la cual, Hanna comenzará a aprender a leer.
} 
Seguí leyendo para Hanna todo lo que me apetecía leer. En el caso de La Odisea, al principio se me hizo difícil concentrarme tanto como lo hacía cuando leía sólo para mí. Pero con el tiempo me fui acostumbrando. El otro inconveniente de la lectura en voz alta es que requiere de más tiempo. Pero, a cambio de eso, lo que leía se me quedaba más grabado en la memoria. Aún hoy me acuerdo muy claramente de bastantes cosas. (Ibíd.: 173)

En este pasaje sobresalen dos cuestiones. Una es la referida a la dificultad en la concentración cuando se lee en voz alta. Como si la atención estuviera puesta en la voz, en la interpretación de aquello que se lee, más que en la comprensión del contenido leído. Por otro lado, como contrapartida, menciona que es más fuerte el recuerdo de lo leído en alta voz, como si la sonoridad material de las palabras - esa materialidad de la voz que excede ampliamente el psiquismo del significante saussureano - relacionada tal vez con las herencias orales de los pueblos, pudiera inscribirse en la memoria de un modo más eficaz que aquello visitado sólo por el ojo. Al respecto, dice De Certeau:

... una memoria cultural adquirida mediante el oído, por medio de la tradición oral, permite y enriquece poco a poco las estrategias de investigación semántica cuyo desciframiento de un escrito afina, precisa o corrige las previsiones. ( ... ) La grafía sólo labra y abre la anticipación. (1996:181)

En la página siguiente, hace algunas apreciaciones que refieren al escritor como lector:

Cuando empecé a escribir yo, le leía también cosas mías. Esperaba hasta haber dictado el manuscrito y revisado la versión escrita a máquina, hasta que tenía la sensación de que aquello ya estaba acabado. Al leer en voz alta sabía si conseguía el efecto deseado. Si no lo conseguía, podía revisarlo todo y volver a grabar encima de lo que ya estaba grabado. Pero no me gustaba hacerlo. Hanna se convertía en la entidad para la que ponía en juego todas mis fuerzas, toda mi creatividad, toda mi fantasía crítica. Luego podía enviar el manuscrito a la editorial. (Schlink; op. cit: 174)

En esa escena aparece una suerte de intercambio de roles. Sin bien la voz que efectivamente leía el texto era la propia, es el autor quien está otorgando a Hanna la categoría de lectora. También era ella la receptora de los textos de Michael, no sólo de aquellos a los que él les prestaba su voz, sino en los que intentaba construir una voz propia. Si enviaba a Hanna esas lecturas o no, nunca lo sabremos, ya que no está explicitado en el texto ni parece haber pistas de ello. De la actividad de Michael como escritor, la película no hace referencia alguna. Pero se podría aventurar que así como él "le da de leer" a Hanna los textos de otros, también le pide a ella implícitamente - un acto de amor: que se convierta en su musa y en su lectora. 


\section{El analfabetismo como verdugo: una metáfora del autoritarismo}

A pesar de que la mayoría de las críticas han dejado un poco de lado el tema del "secreto" de Hanna — del cual dice la reseña de Página 12: "un secreto que importa menos en sí mismo que como disparador dramático" - algunas cuestiones tanto en la novela como en el filme resultan significativas. En primer lugar, el analfabetismo de Hanna —o más bien su vergüenza frente a la ignorancia que la lleva a hacer esfuerzos innominables para ocultarla - se presenta como un factor desencadenante en la vida de la protagonista. Las decisiones que toma $-\mathrm{o}$, al menos, muchas de ellas: alistarse en las SS fue la más contundente y la que le trajo mayores consecuencias - son diseñadas en función de ocultar su imposibilidad.

Esta situación que algunas de las críticas a la película consideran excesiva e incluso, tal vez, inverosímil, despierta preguntas en el propio protagonista de la novela, quien, cuando narra el momento en que cae en la cuenta del secreto de Hanna, afirma:

Yo podía comprender que se avergonzara de no saber leer ni escribir, y que hubiera preferido comportarse de una manera inexplicable conmigo antes que permitir que la desenmascararse. Al fin y al cabo, yo sabía por propia experiencia que la vergüenza puede forzar a uno a mostrarse esquivo, a ponerse a la defensiva, a ocultarse y desfigurar las cosas, incluso a herir a los demás. Pero zera posible que la vergüenza explicara también el comportamiento de Hanna durante el juicio y en el campo de concentración? ¿Que prefiriera ser acusada de un crimen a pasar por analfabeta? ¿Cometer un crimen por miedo a pasar por analfabeta? (...) ¿Por qué prefería un desenmascaramiento inofensivo, el de su analfabetismo, a otro muchísimo peor, el de sus crímenes? (... ) ¿Y de verdad era tan vanidosa y malvada como para convertirse en una criminal con tal de no quedar en ridículo?” (Schlink; op. cit: 124).

Buscar una respuesta a la pregunta por el analfabetismo es complejo desde una sociedad "alfabética". Consultado sobre esta situación en Alemania durante una entrevista, el autor responde:

No sólo es un problema de los países del tercer mundo; en los países industrializados de Europa hay altas tasas de analfabetismo: un tres por ciento de la población alemana es analfabeta; lo que ocurre es que no lo queríamos aceptar. Los analfabetos sienten tanta vergüenza que hacen todo tipo de trucos para ocultar su condición, como comprarse el diario cada mañana y sentarse en un café a hacer de cuenta que lo leen. $\mathrm{O}$ si en la calle se pierden y no saben dónde están dicen que se olvidaron los anteojos y que por eso no alcanzan a leer el cartel. (Página $12 \mathrm{del} 4 / 5 / 2005$ )

Un sitio alemán reafirma lo expresado por Schlink:

... hay ejemplos de alemanes que logran concluir una vida laboral, de mayor o menor éxito, disimulando que no saben ni leer ni escribir. Tal es el caso de Berri, de 57 años de edad, que se salía de algún aprieto inventando, por ejemplo, que se había olvidado los lentes en casa. Valiéndose 
únicamente de su gran memoria, logró trabajar de minero, obrero de la construcción e incluso estuvo al mando de un restaurante. Nadie se percató jamás de que Berri era analfabeto, ni siquiera sus amigos. (Rissi, 2004: s/n)

El protagonista, más adelante vuelve a afirmar:

Durante aquellos años, yo había leído todo lo que había encontrado sobre analfabetismo. Sabía de la impotencia ante situaciones totalmente cotidianas, a la hora de encontrar el camino para ir a un lugar determinado o de escoger un plato en un restaurante; sabía de la angustia con que el analfabeto se atiene a esquemas invariables y rutinas mil veces probadas, de la energía que cuesta ocultar la condición de analfabeto, un esfuerzo que acaba marginando a la persona del discurrir común de la vida. El analfabetismo es una especie de minoría de edad eterna ${ }^{12}$. Al tener el coraje de aprender a leer y escribir, Hanna había dado el paso que llevaba de la minoría a la mayoría de edad, un paso hacia la conciencia. (Schlink; op. cit.: 176)

El amor a la literatura, la falta de libertad y la voz de un antiguo amor son en esta historia los motores que hacen que Hanna, en soledad, busque y encuentre un modo de aprender a leer. En una de las escenas más conmovedoras del filme, profundamente cinematográfica — es decir, con tal fuerza visual que la convierte en uno de los grandes aciertos de la adaptación - se ve la emoción de Hanna ante la voz de Michael en la grabadora, sentada frente a un libro impreso. Es evidente la determinación en su rostro, la torpeza con la que toma un lápiz y en una suerte de revelación cuenta las primeras cuatro palabras que la voz emite y luego cuenta, marcando con el lápiz, las primeras palabras escritas en la portada del libro: "La dama del perrito". Encierra a una de ellas con un círculo y hace lo mismo cada vez que encuentra esa misma palabra, esa misma grafía en la página que está intentando comenzar a decodificar. La escena recuerda el testimonio de un predicador inglés, Thomas Johnson quien

explicaba que aprendió a leer estudiando las letras en una Biblia que había robado. Como su amo leía todas las noches en voz alta un capítulo del nuevo testamento, Johnson consiguió convencerlo de que leyera el mismo varias veces seguidas hasta que se lo aprendió de memoria y luego pudo encontrar las mismas palabras en la página impresa (... ) más adelante, creó su propia escuela para enseñar a otros a leer. (Manguel, op. cit: 291)

Más allá de la belleza de la escena, es significativo el hecho de que Hanna, una vez sancionada por sus crímenes en los que, según manifiesta en la novela, no había vuelto a pensar hasta el momento del juicio ${ }^{13}$, haya decidido salir de esa "minoría de edad"14 aprendiendo a leer. Aquí es

\footnotetext{
12 Esta consideración de Michael hace pensar en el planteo kantiano acerca de la llustración como una suerte de mayoría de edad. "La llustración consiste en el hecho por el cual el hombre sale de la minoría de edad. Él mismo es culpable de ella. La minoría de edad estriba en la incapacidad de servirse del propio entendimiento, sin la dirección de otro" (Kant; 2004: 33).

13 Podría hacerse aquí alguna reflexión acerca de la relevancia de la sanción social, no sólo como castigo a los criminales, sino como modo de inscripción simbólica de lo permitido y lo prohibido, de lo moralmente correcto o incorrecto.
} 
donde pareciera borrarse ese ánimo "veladamente complaciente" como la calificó La Nación para convertirse, tal vez, en una gran metáfora del analfabetismo como consecuencia deseada de un fuerte autoritarismo. Dejar que otros lean para uno, dejarles a otro el poder de descifrar para nosotros lo que otros han escrito - el término descifrar, encierra, también en este caso, la idea de interpretar, de dar sentido - requiere de una gran cuota de confianza en quien lee, pero también implica una gran porción de poder para el lector. No en vano las dictaduras se han ensañado reiteradamente con los libros por un lado ${ }^{15}$, mientras implementaban políticas que lejos estaban de la promoción de la alfabetización.

Este planteo no pretende presentar a Hanna como a una víctima del nazismo, cuando en realidad, fue un verdugo. Sin embargo, parece vislumbrarse en la historia algo del orden de la metáfora respecto del autoritarismo y la falta de conciencia, de una parte; y de la alfabetización como una suerte de toma de conciencia que lejos está de la redención, por la otra.

\section{Algunas breves ideas finales}

Más allá de las diferencias mencionadas entre el relato literario y el cinematográfico, El Lector puede analizarse como un mismo discurso sobre la sociedad alemana del post nazismo, a partir de una historia de amor no exenta de zonas oscuras ni aspectos escabrosos. Pese a la incomodidad que puede haber generado en alguno de sus receptores, la historia parece intentar develar la complejidad de una sociedad que debe enfrentar un pasado terrible, que siente sobre sus espaldas el deber de condenar pero que también necesita imperiosamente comprender. Esta empresa parece imposible. ¿Cómo condenar y comprender al mismo tiempo? ¿Cómo ver en la mujer amada también a un verdugo, a alguien que luego de "usar" a algunas prisioneras débiles como lectoras para satisfacer su sed de relatos, de literatura, de arte, podía enviarlas insensiblemente a la muerte?

El suicidio final de Hanna un día antes de su liberación, no forma parte de la expiación de sus culpas ni la redime. Sin embargo, parece llamativo que la vida en prisión le hubiera sido soportable, mientras que la recuperación de la libertad pareciera significarle una condena imposible de tolerar. ¿Cómo ser mayor de edad de golpe — para reiterar la imagen de Michael— en un mundo desconocido?

Esta es una pregunta — una más entre todas las que la historia plantea— para la que tampoco hay respuesta.

\footnotetext{
${ }^{14}$ De alguna manera, esta idea del analfabetismo como una minoría edad permanente y de la alfabetización como la entrada al mundo de la conciencia, nos remite a los planteos de Paulo Freire sobre la función emancipadora que tiene la capacidad de leer y escribir. Para el pedagogo brasilero, no se trata sólo de poder leer y escribir letras, sino que la alfabetización implica la capacidad de leer y escribir — cambiar- el mundo.

${ }^{15}$ La imagen de personas quemando sus propios libros como manera de protegerse y la lista de lecturas y escritores prohibidos forman parte ya de la iconografía de la censura durante la última dictadura militar argentina. Sobre la misma Alemania, Manguel refiere a una quema de libros en Berlín durante 1933, delante de la cual el ministro de propaganda Goebbels daba un discurso acalorado sobre la relevancia de quemar lo que él llamaba las obscenidades del pasado (Cfr. Manguel, Op. cit: 293).
} 


\section{Referencias}

Agamben, G. (2000) Lo que queda de Auschwitz. Valencia: Pretextos

De Certeau, M. (1996) “Leer: una cacería furtiva”. En: La invención de lo cotidiano I. Artes de hacer. Ciudad de México: Universidad Iberoamericana.

Huyssen, A. (2001) "El Holocausto como historieta. Una lectura de Maus de Spiegelman”. En: En busca del futuro perdido. Cultura y memoria en tiempos de globalización. Buenos Aires: Fondo de Cultura Económica.

------ (2006) “La política de la identificación: 'Holocausto’ y el drama en Alemania Occidental”. En: Después de la gran división. Modernismo, cultura de masas, posmodernismo. Buenos Aires: Adriana Hidalgo.

Kant, I. (2004) “Respuesta a la pregunta ¿Qué es la Ilustración?”. En: Filosofía de la Historia. Qué es la Ilustración. La Plata: Terramar.

Levy, P. (1998) Entrevistas y conversaciones. Barcelona: Península.

Manguel, A. (2005) Una historia de la lectura. Buenos Aires: Emecé.

Moreno Ocampo, L. (1996) Cuando el poder perdió el juicio. Cómo explicar el 'Proceso' a nuestros hijos. Buenos Aires: Planeta.

Nordmann, I. (1991) "Hannah Arendt: Las vías hacia la acción y el pensamiento políticos". Separata Revista Debats No 37.

Pennac, D. (2004) Como una novela. Bogotá: Norma.

Petrucci, A. (1998) “Leer por leer, un porvenir para la lectura”. En: Cavallo, G. y Cartier, R. (dir.) Historia de la lectura en el mundo occidental. Madrid: Taurus.

Sarlo, B. (2005) Tiempo pasado. Cultura de la memoria y giro subjetivo. Una discusión. Buenos Aires: Sigo XXI.

\section{Material periodístico consultado}

“Bernhard Schlink, El lector”. Leyendo a la sombra. 13 de julio de 2005. Obtenido el 5 de febrero de 2010 en http://leyendoalasombra.blogia.com/2005/071301-bernahrd-schlink-ellector.php

“Stephen Daldry: 'Le Liseur, c'est la banalité du mal”. Entrevista en Le Figaro del 15 de julio de 2009, (traducción propia), obtenida el 2 de febrero de 2010 en http://www.lefigaro.fr/cinema/2009/07/15/03002-20090715ARTFIG00011-stephendaldry-8220le-liseur8221-c-est-la-banalite-du-mal-php.

Bernades, H. (2009, 7 de mayo) “Preguntas sin respuestas”. Página 12. Obtenida el 2 de febrero de 2010 en http://www.pagina12.com.ar/diario/suplementos/espectaculos/5-13781-200905-07.html

Brody, R. (2009, 26 de febrero) "Bernhard Schlink on The Reader". The Front Row de The Newyorker, (traducción propia). Obtenida el 4 de febrero de 2010 en http://www.newyorker.com/online/blogs/movies/2009/02/bernhard-schlin.html 
Dargis, M. (2008, 10 de diciembre) “Innocence Is Lost in Postwar German”. New York Times (traducción propia). Obtenido el 4 de febrero de 2010 en http://movies.nytimes.com/2008/12/10/movies/10read.html

Franz, C. (2005) "Bernhard Schlink, hipócrita lector..." Obtenido el 6 de febrero de 2010 en http://www.cervantesvirtual.com/servlet/SirveObras/23581730981236186343679/p0 000001.htm

Friera, S. (2005, 4 de mayo) "Cuando uno toma distancia es más fácil ver los matices". Entrevista a Bernard Schlink. Página 12. Obtenido el 6 de febrero de 2010 en http://www.pagina12.com.ar/diario/cultura/7-50542-2005-05-04.html

López, F. (2009, 7 de mayo) "El lector, el amor en los tiempos de la culpa". La Nación. Obtenido el 2 de febrero de 2010 en http://www.lanacion.com.ar/nota.asp?nota_id=1125141

Rissi, V. (2004, 3 de agosto) "Alemania está llena de analfabetos", obtenido el 5 de febrero de 2010 en http://www.dw-world.de/dw/article/0,1286212,00.html

Scholz, P. (2009, 7 de mayo) "Los imperdonables". Clarín. Obtenida el 2 de febrero de 2010 en http://www.clarin.com/diario/2009/05/07/espectaculos/c-01101.htm 